\title{
Tulane
}

\author{
Tulane Economics Working Paper Series
}

\section{Mobility, Competition, and the Distributional Effects of Tax Evasion}

\author{
James Alm \\ Department of Economics \\ Tulane University \\ New Orleans, LA \\ jalm@tulane.edu
}

\author{
Edward B. Sennoga \\ Uganda Field Office \\ African Development Bank \\ Kampala, Uganda \\ e.sennoga@afdb.org
}

\section{Working Paper 1108}

April 2011

\begin{abstract}
The standard assumption underlying the incidence of tax evasion is that the beneficiaries are those who successfully evade their taxes. However, a general equilibrium process of adjustment should occur through changes in the relative prices of both commodities and factors of production as resources move into and out of the relevant activities, and these changes should tend to reduce any initial benefit from evasion. In this paper we analyze these incidence effects, using a computable general equilibrium model of an economy with a formal (and taxed) sector and an informal (and untaxed) sector, in order to examine how much of the initial benefit of income tax evasion is retained by the evaders and how much is shifted via factor and commodity price changes stemming from mobility. Our simulation results show that the household that successfully evades its income tax liabilities has a post- evasion welfare that is only slightly higher than its post-tax welfare if it had fully complied with taxes. Further, while this household keeps some of its initial increase in welfare, a large percentage of this initial gain is competed away as a result of mobility that reflects competition and entry into the informal sector. Consequently, the evading household benefits only marginally from successful income tax evasion, and this advantage diminishes with mobility via competition/entry in the informal sector.
\end{abstract}

Keywords: tax evasion, computable general equilibrium model, social accounting matrix JEL: H26, H22 


\title{
MOBILITY, COMPETITION, AND THE DISTRIBUTIONAL EFFECTS OF TAX EVASION
}

\author{
James Alm and Edward B. Sennoga
}

\section{SUMMARY}

The standard assumption underlying the incidence of tax evasion is that the successful evader keeps the evaded income in its entirety, so that the beneficiaries of evasion are those who successfully evade their taxes. However, this assumption is likely to be incorrect, or least incomplete. Those who benefit from tax evasion are not necessarily the individuals actually engaging in evasion; indeed, these participants may not benefit at all. In many situations tax evasion can be viewed as a "tax advantage" generated by the tax laws. If there is any advantage at all, we would expect replication and competition via the mobility of factors and products to work toward the elimination of this advantage. Put differently, a general equilibrium process of adjustment should occur through changes in the relative prices of both commodities and factors of production as resources move into and out of the relevant activities, and these changes should tend to eliminate, or at least to reduce, the initial tax advantage of tax evasion. These types of general equilibrium effects are not typically considered in the standard approach to tax evasion.

This omission considerably weakens the relevance of the standard approach, at least in its conclusions about the distributional effects of tax evasion. If it is simpler to hide, say, capital income as opposed to labor income, then the standard approach concludes that (successful) evasion will make the tax system less progressive; in contrast, if lower-income groups can evade taxes more easily, then the usual conclusion is that evasion will make the tax system more progressive. However, these types of inferences may not be correct, if the advantage of evading gets capitalized or competed away by market adjustments. An obvious case in point is tax evasion by domestic help, such as house cleaners, baby sitters, and yard care workers. Tax evasion here may actually benefit the higher-income households hiring these services because they can pay lower prices for these services. However, these (and other) types of adjustments have not typically been considered in most previous work on the distributional effects of tax evasion.

In this paper we analyze the incidence effects of these adjustment processes, using a computable general equilibrium model of an economy with a formal (and taxed) sector and an informal (and untaxed) sector. We incorporate the individual's decision to evade, and we also allow for varying degrees of mobility via competition and/or entry across sectors in the economy. We examine how much of the initial tax advantage is retained by income tax evaders and how much is shifted via factor and commodity price changes stemming from mobility. Our simulation results show that a household that successfully evades its income tax liabilities has a post-evasion welfare that is only 1.1-3.4 percent higher than its post-tax welfare if it had fully complied with the income tax. Further, this household keeps only 75.3-78.2 percent of its initial increase in welfare, while 21.8-24.7 percent of its initial gain is competed away as a result of mobility that reflects competition and entry into the informal sector. Although the initial post-evasion welfare effect is negative for the household that complies with income taxes, its welfare increases by 87.5-142.3 percent with competition and entry in the informal sector. Consequently, and consistent with the erosion of the initial benefits of tax evasion via general equilibrium adjustments, the evading household benefits only marginally from successful income tax evasion, and this advantage diminishes with mobility via competition/entry in the informal sector. 


\section{James Alm and Edward B. Sennoga}

The standard assumption underlying the incidence of tax evasion is that the beneficiaries are those who successfully evade their taxes. However, a general equilibrium process of adjustment should occur through changes in the relative prices of both commodities and factors of production as resources move into and out of the relevant activities, and these changes should tend to reduce any initial benefit from evasion. In this paper we analyze these incidence effects, using a computable general equilibrium model of an economy with a formal (and taxed) sector and an informal (and untaxed) sector, in order to examine how much of the initial benefit of income tax evasion is retained by the evaders and how much is shifted via factor and commodity price changes stemming from mobility. Our simulation results show that the household that successfully evades its income tax liabilities has a postevasion welfare that is only slightly higher than its post-tax welfare if it had fully complied with taxes. Further, while this household keeps some of its initial increase in welfare, a large percentage of this initial gain is competed away as a result of mobility that reflects competition and entry into the informal sector. Consequently, the evading household benefits only marginally from successful income tax evasion, and this advantage diminishes with mobility via competition/entry in the informal sector.

Keywords: tax evasion, computable general equilibrium model, social accounting matrix JEL Codes: H26, H22

James Alm: Department of Economics, Tulane University, 6823 St. Charles Avenue, 208 Tilton Hall, New Orleans, LA 70118 USA (phone 504862 8344; fax 504865 5869; email jalm@tulane.edu).

Edward B. Sennoga: African Development Bank, Uganda Field Office, $14^{\text {th }}$ Floor Crested Towers Building, P.O. Box 28509, Kampala, UGANDA (phone +256 774 256196; fax +256 414 234011; email: e.sennoga@afafb.org). 


\section{INTRODUCTION}

The standard approach to the analysis of tax evasion assumes that an individual weighs the expected utility of successful evasion with the risky prospect of detection and punishment (Allingham and Sandmo, 1972). The implicit assumption here is that the successful evader keeps the evaded income in its entirety, so that the beneficiaries of evasion are those who successfully evade their taxes. However, this assumption is likely to be incorrect, or least incomplete. Those who benefit from tax evasion are not necessarily the individuals actually engaging in evasion; indeed, these participants may not benefit at all. In many situations tax evasion can be viewed as a "tax advantage" generated by the tax laws (Martinez-Vazquez, 1996). If there is any advantage at all, we would expect replication and competition via the mobility of factors and products to work toward the elimination of this advantage. Put differently, a general equilibrium process of adjustment should occur through changes in the relative prices of both commodities and factors of production as resources move into and out of the relevant activities, and these changes should tend to eliminate, or at least to reduce, the initial tax advantage of tax evasion. These types of general equilibrium effects are not typically considered in the standard approach to tax evasion.

This omission considerably weakens the relevance of the standard approach, at least in its conclusions about the distributional effects of tax evasion. If it is simpler to hide, say, capital income as opposed to labor income, then the standard approach concludes that (successful) evasion will make the tax system less progressive; in contrast, if lower-income groups can evade taxes more easily, then the usual conclusion is that evasion will make the tax system more progressive. However, these types of inferences may not be correct, if the advantage of evading gets capitalized or competed away by market adjustments. An obvious case in point is tax evasion by domestic help, such as house cleaners, baby sitters, 
and yard care workers. Tax evasion here may actually benefit the higher-income households hiring these services because they can pay lower prices for their services. However, these (and other) types of adjustments have not typically been considered in most previous work on the distributional effects of tax evasion.

In this paper we analyze the incidence effects of these adjustment processes, using a computable general equilibrium (CGE) model of an economy with a formal (and taxed) sector and an informal (and untaxed) sector. In our model, we incorporate the individual's decision to evade via an approach suggested by Thalmann (1992), and we also allow for varying degrees of mobility via competition and/or entry across sectors in the economy. We examine how much of the initial tax advantage is retained by income tax evaders and how much is shifted via factor and commodity price changes stemming from mobility. Our simulation results show that a household that successfully evades its income tax liabilities has a post-evasion welfare that is only 1.1-3.4 percent higher than its post-tax welfare if it had fully complied with the income tax. Further, this household keeps only 75.3-78.2 percent of its initial increase in welfare, while 21.8-24.7 percent of its initial gain is competed away as a result of mobility that reflects competition and entry into the informal sector. Although the initial post-evasion welfare effect is negative for the household that complies with income taxes, its welfare increases by 87.5-142.3 percent with competition and entry in the informal sector. Consequently, and consistent with the erosion of the initial benefits of tax evasion via general equilibrium adjustments, the evading household benefits only marginally from successful income tax evasion, and this advantage diminishes with mobility via competition/entry in the informal sector.

In the following sections, we present a brief overview of significant previous research on tax evasion incidence, highlighting some of the gaps in the literature. We then develop a CGE model tailored to mirror a "typical" small closed and developing economy. 
We follow with the details of our model calibration and a discussion of our simulation results. The final section concludes.

\section{SOME RELATED RESEARCH}

In their seminal work, Allingham and Sandmo (1972) consider the case of an individual's decision to evade income taxes. They apply a portfolio approach to tax evasion, in which individuals compare the expected utility of being detected and paying a penalty on tax evasion to the expected utility from being able to keep the evaded income. The incidence of tax evasion in this formulation is simple: the successful evader benefits exclusively by keeping the evaded income in its entirety. However, this approach ignores market forces that work toward the elimination of the tax advantage created by evasion opportunities via changes in both commodity and factor prices, as products and resources flow into and out of affected activities. These forces can only adequately be analyzed in a general equilibrium framework.

Several studies have in fact examined tax evasion (and closely related issues like the so-called "underground economy") with such a general equilibrium approach, building upon the model originally pioneered by Harberger (1962). For example, Alm (1985) uses a standard two-factor, three-sector model to assess the welfare cost of taxes that drive factors into the untaxed underground economy. However, in order to focus upon the efficiency aspects of the underground economy, he assumes a single representative agent, and so cannot examine the distributional effects of these general equilibrium adjustments; he also does not allow for uncertainty in the agent's decisions, so that he cannot examine the underlying tax evasion choices of the agent. In perhaps the most complete analysis of general equilibrium effects of income tax evasion, Kesselman (1989) develops a multiconsumer, multi-sector general equilibrium model, which allows him to make qualitative 
and quantitative assessments of the effects of tax rate changes on evasion activity, relative output prices, and real tax revenues. ${ }^{1}$ Although Kesselman (1989) allows for individual heterogeneity via multiple consumers and so can examine the distributional effects of evasion, he does not allow for uncertainty in individual evasion decisions.

Some other work allows for such uncertainty. For example, Watson (1985) analyses a model with two labor markets that offer differing evasion possibilities, in order to examine the effects of changes in tax, penalty, and audit rates on the allocation of labor across labor markets. However, Watson (1985) allows only for labor (and not capital) markets, which means that he cannot examine the full range of general equilibrium price and incidence effects that evasion may create. ${ }^{2}$

Like Watson (1985), Thalmann (1992) also introduces uncertainty into the individual evasion decision. In his general equilibrium framework, taxes are evaded when resources relocate from the "reported" sector to the "unreported" sector. Of some relevance to our approach here, Thalmann (1992) uses a novel approach that relegates the uncertainty of returns associated with tax evasion to the budget constraint rather than follow the usual expected utility approach. However, Thalmann (1992) assumes a single "representative" agent, and so he is not able to examine fully the distributional effects of evasion.

These studies have added considerably to our understanding of the general equilibrium adjustments that occur in the presence of tax evasion. ${ }^{3}$ Even so, this work does

\footnotetext{
1 For example, Kesselman (1989) finds that higher tax rates drive resources out of the compliant sector into the evading sector, if government consumes goods from both the evading and compliant sectors in the same pattern as households and if higher tax rates do not affect evasion costs. However, if government purchases are biased toward output of the compliant sector and if higher tax rates also raise the evasion costs for individuals via, say, the structure of penalties for the apprehended evaders, then higher tax rates may actually lower tax evasion.

2 Indeed, Watson $(1985,243)$ himself writes that "...we have not discussed the potential inequities produced by evasion".

3 For some other general equilibrium treatments of tax evasion, see Jung, Snow, and Trandel (1993) and Davidson, Martin, and Wilson (2007). However, these studies focus mainly on the how evasion affects allocative efficiency (e.g., Davidson, Martin, and Wilson, 2007), or on how taxation affects the size of the
} 
not address fully the main issues surrounding the distributional effects of tax evasion. There is no single study that has explicitly incorporated all of the general features that we believe a model must have in order to capture these distributional effects.

What are these general features? As argued by Martinez-Vazquez (1996), there are several desirable features for models of evasion incidence.

First, the model should be able to capture the potential general equilibrium effects of tax evasion. These general equilibrium effects induce changes in the relative prices both of factors of production and of goods and services, brought about by market equilibrium forces. If there is a tax advantage in terms of expected factor income or firms' expected profits, the (potential) mobility of resources will lead to the necessary price adjustments until this advantage is eliminated.

Second, the model should incorporate the element of uncertainty in an individual's decision to evade in at least one sector of the economy. This uncertainty may reflect simply the element of tax evasion as an opportunity facing the individual; more broadly, it may reflect the possibility that at some point the individual may be subject to taxation. The presence of uncertainty is an essential characteristic of tax evasion incidence, and allows the excess burdens of evasion associated with uncertainty to be accounted for in the model.

Third, the model should allow for varying degrees of competition or entry across sectors in the economy, including those in which tax evasion is prevalent. This includes mobility of factors, such as labor in the case of income tax evasion; it also includes firm entry in several sectors, as in the case of sales tax or corporate income tax evasion. The element of mobility is critical to an understanding of how much of the tax advantage may be retained by the initial evaders and how much is shifted elsewhere via factor and commodity 
price changes. ${ }^{4}$

A complete analysis of the incidence of tax evasion therefore requires the consideration of these general equilibrium effects, in a setting in which uncertainty is present and in which mobility across sectors can vary. At one extreme, with no entry or competition, those participating in evasion activities are the final beneficiaries, as the standard approach predicts. At the other extreme, with perfect competition and completely free entry, tax evaders (even if successful) may hardly benefit at all because any initial benefit from the absence of taxation is eroded via entry and competition.

The failure to consider these adjustments can lead to a variety of mistakes. As one example, Skinner and Slemrod (1985) argue that, if labor income is more likely to be generated in the untaxed sector than capital income, then the existence of tax evasion makes the tax system more progressive. However, if the advantages realized by workers get capitalized or competed away by market processes, then this conclusion is incorrect. The failure to tax, say, domestic help may actually benefit higher-income households who hire these services because entry into domestic help means that the households pay lower prices for the domestic services. Similarly, immigrant or undocumented workers working in, say, the garment industry may not benefit from any success in evading taxes. Instead, with entry it is rather the buyers of garments who benefit from lower prices of the various commodities that are produced by individuals who do not pay taxes.

A second example is demonstrated by Persson and Wissen (1984), who analyze the relationship between the true distribution of income (which includes income on which no taxes are paid) and the distribution of officially reported income. Given the differences

\footnotetext{
${ }^{4}$ There are several other features that a complete model should incorporate. For example, it would be desirable to allow for differences in preferences among individuals so that different groups may benefit differently from changes in relative prices. It would also be desirable to incorporate any of the externality effects that evaders may impose on others. The advantages of evasion may also be dissipated by direct means, such as bribes to corrupt officials (Shah and Whalley, 1996), so that the model should allow for this and other types of corruption.
} 
between the two, they correctly conclude that government policies aimed at reducing the inequality in the distribution of reported income could be counterproductive in terms of actual income distributions. However, they also implicitly assume that the incidence of tax evasion is simple and direct: evaders benefit exclusively and fully from their failure to pay taxes. If the incidence of evasion is more indirect and more complicated, then the government might stop redistribution efforts based on the belief that certain groups are already benefiting from tax evasion, when actually they are not; similarly, the government may not go far enough in its redistribution, based on an incorrect belief that low income tax cheats are benefiting more from evasion than they really are.

Empirical studies of the distribution of tax burdens provide a third, and perhaps the most important, example of the use of naive assumptions about the incidence of evasion. It is a traditional exercise in public finance to examine the progressivity or regressivity of a particular tax system, and the study of the overall incidence of new proposals for tax reform is almost always part of the background work accompanying a reform. Frequently, findings of vertical and horizontal incidence are adjusted to take into account the impact of existing evasion, such as in the case of professionals or unskilled workers employed in the informal sector of the economy. These adjustments are made under the assumption that the evading groups benefit exclusively and in full from the assumed tax evasion. Indeed, Alm, Bahl, and Murray (1991) conduct this type of analysis for Jamaica, in which they generate estimates of the amount of tax evasion that occurs via underreporting of income and nonfiling of income tax returns, in order to derive estimates of the "true" burden of taxation in Jamaica. However, they assume that tax evaders retain all benefits from their evasion. In many cases this implicit assumption is incorrect, and the resulting estimates of the "true" burden of taxation are therefore misleading.

The key phenomenon that any model should explain is to extent to which any 
advantage of tax evasion gets capitalized or competed away via price changes, including the identification of gainers and losers from this process. A complete model of incidence should also allow us to reach a wide variety of conclusions. As noted above, at one extreme we might have the case in which there is "no shifting" at all because, for example, there is no mobility or no free entry. In this case, successful evaders keep all unpaid taxes in their entirety, and there are no changes in relative prices of factors of production or commodities as a result of the evasion activity itself. ${ }^{5}$ At the other extreme we might have the case in which the tax advantage gets "fully shifted" elsewhere because entry is unrestricted and the supply response is large enough to compete away any residual tax advantage. This could happen if, for example, there is a very elastic supply of potential taxpayers who may have no choice but to work in the untaxed or informal sector, such as the presence of unskilled laborers in a developing economy with limited opportunities for employment, or the existence of undocumented workers in a developed economy who also have limited opportunities. In these cases, it is unlikely that these workers would be able to keep any benefit from working in an informal sector. Instead, the likely beneficiaries are buyers of the goods and services produced in the informal sector. ${ }^{6}$

We utilize these guidelines to develop a framework for analyzing the incidence of tax evasion via a static CGE model, as discussed next.

\section{A STATIC COMPUTABLE GENERAL EQUILIBRIUM MODEL ${ }^{7}$}

\footnotetext{
${ }^{5}$ Limits to entry may reflect the fact that buyers prefer to buy from reputable merchants with products under warranty. Limits to entry may also come from risk aversion, higher costs for concealing taxes, fear of stigma, or even the need to show some degree of compliant behavior to conceal other taxes due from the authorities. See Kesselman (1989).

6 A special case here is one in which the commodities are consumed exclusively by higher income groups.

7 The framework presented draws largely on Sennoga (2006). The full algebraic representation of the model is available upon request.
} 
Our computable general equilibrium (CGE) model depicts a small static closed

economy with two broadly defined sectors, composed of an aboveground (or taxed) sector that produces output $x$ and an underground, informal, or tax evading sector whose output $y$

is a substitute for taxed output. We make several main assumptions:

- There are two consumers, a POOR household working entirely in the informal sector and a RICH household working only in the formal sector. ${ }^{8}$

- Labor is variable in supply, with a standard labor-leisure choice, and is imperfectly mobile across sectors. ${ }^{9}$

- Capital is fixed in total supply, imperfectly homogenous, imperfectly mobile across sectors, and fully taxed. ${ }^{10}$

- Labor income generated in the aboveground sector (sector $\chi$ ) is fully taxed at rate $t$.

- Labor income generated in the underground sector (sector $y$ ) is hidden from the authorities and may escape taxation; however, this income may be detected and penalized. $^{11}$

- Consumption of both sectors is subject to an indirect tax at rate $\tau$.

- Sector $x$ consumption is fully taxed; sector $y$ consumption may escape taxation, but this indirect tax evasion may be detected and penalized.

- Spending and income of the government (GOVT) are disaggregated from that of the consumers, so that the government is treated as a separate consumer that collects taxes in order to provide a public good called "public administration".

Also, producers are assumed to maximize profits taking prices as given, and consumers are assumed to maximize utility subject to a budget constraint that depends upon the value of their endowments. These assumptions imply that producers earn only normal profits and that consumers cannot increase consumption of all goods.

\footnotetext{
${ }^{8}$ Note that in some of our simulations we also allow the RICH household to allocate some of its labor to the informal sector (as well as to the formal sector). This is discussed in more detail below.

${ }^{9}$ For a Cobb-Douglas function with an elasticity of substitution between consumption and leisure equal to one, labor supply is completely inelastic with respect to the wage rate. However, when the elasticity of substitution is greater than one, an increase in the wage rate will generate an increase in labor supply, and an elasticity of substitution less than one will mean that labor supply falls with an increase in the wage rate, leading to a "backward bending" supply curve. As discussed later, we allow for multiple values of the elasticity of substitution in our sensitivity analysis.

${ }^{10} \mathrm{Alm}$ (1985) argues that the presence of risk premia on factor returns in the underground sector will prevent complete equalization of net factor returns, even with complete mobility. It is important to note that it is factor returns adjusted for any such differentials that are equalized by mobility. To the extent that the pattern of risk premia is not affected by the presence of these taxes, the results remain unchanged.

${ }^{11}$ Also, firms in this sector may be constrained by concealment requirements. For instance, firms in the underground sector may opt to produce less than the profiting maximizing level of output to avoid detection in the evasion of sales taxes.
} 


\section{A. Household Consumption and Labor Decisions}

The RICH and POOR consumers allocate their time to labor in the formal and informal sectors, respectively, and to leisure according to the following utility maximization problem:

$$
U=\operatorname{Max} U^{i}\left(C_{j}^{i}, H^{i}-L_{x}^{i}-L_{y}^{i}\right), i=1,2 \text { and } j=x, y
$$

subject to

$$
(1+\tau) P_{x} C_{x}^{i}+\left[1+P^{\tau i}\left(a^{\tau}, \tau\right)\right] P_{y} C_{y}^{i} \leq(1-t) w_{x} L_{x}^{i}+\left[1-P^{t i}\left(a^{t}, t\right)\right] w_{y} L_{y}^{i}+(1-t) r_{x} K_{x}^{i}+r_{y} K_{y}^{i}
$$

where

$C_{j}^{i}$ is consumption by individual $i$ of the commodity produced by sector $j$,

$$
(j=x, y)^{12}
$$

$P_{j}$ is the (producer) price of $\operatorname{good} j,(j=x, y)$

$H^{i}$ is individual $i$ 's total time endowment $(\mathrm{i}=1,2)$, with " 1 " denoting RICH and "2" denoting POOR

$L_{x}^{i}$ and $L_{y}^{i}$ are labor allocated by individual $i$ to sectors $x$ and $y$, and $w_{x}$ and $w_{y}$ are the corresponding real wage rates ${ }^{13}$

Consumption in each sector $j$ is subject to an indirect tax at rate $\tau$

Labor and capital income taxes are proportional to gross income at rate $t$

$P^{t i}($.$) is individual i's expected tax-plus-penalty rate (or expected penalty) for$ evading labor income taxes, and is a general function of the income tax rate $t$ and the income tax enforcement parameter $a^{t} 14$

$P^{\tau i}($.$) is individual i$ 's expected tax-plus-penalty rate for evading the indirect tax on sector $y$ consumption, and is a function of the indirect tax rate $\tau$ and the indirect tax enforcement parameter $a^{\tau 15}$

\footnotetext{
${ }^{12}$ The elasticity of substitution between goods $X$ and $y$ in final demand is assumed to be 1 . However, the informal sector good is assumed to be tainted by the lack of certain attributes like return service, warranty, and after-sales-service otherwise enjoyed by consumers of the formal sector good $X$.

${ }^{13}$ Note that the labor supplied by the RICH household to the informal sector $L_{y}^{1}$ is restricted to zero in equation (2), and also that labor supplied to the formal sector by the POOR household $L_{x}^{2}$ is also restricted to zero. These restrictions reflect the assumption that the RICH household operates only in the formal sector while the POOR household only works in the informal sector. However, as discussed later, we also conduct simulations where we allow the RICH household to allocate some of its labor to the informal sector.

${ }^{14}$ An alternative approach to modeling the risk of detection is to allow the expected penalty rate to vary positively with the amount of evasion or the amount of labor supplied to the informal sector. This extension is left for future research.

${ }^{15}$ Note that the indirect tax on consumption of sector $X$ output cannot be evaded, so that the (effective) tax rate $\tau_{X}$ on $X$ is simply $\tau$. As indicated, the expected tax-plus-penalty rate on sector $y$ is $\tau_{y}=P^{i}\left(a^{\tau}, \tau\right)$.
} 
$K_{x}^{i}$ and $K_{y}^{i}$ are capital allocated by individual $i$ to sectors $x$ and $y$, and $r_{x}$ and $r_{y}$ are the corresponding capital rental rates. ${ }^{16}$

Note that wages need not be equal for a consumer to be active in both sectors. Labor and capital income are fully taxed in the aboveground sector, while unreported labor income in sector $y$ entails the risk of detection and punishment at a penalty rate above the regular tax rate, as captured by $P^{t i}($.$) . Also, consumption of both sectors output is subject to an$ indirect consumption tax, but consumption of informal sector output (by either POOR or RICH households) may be able to evade this tax with some risk of detection and punishment, as captured by $P^{x i}(\cdot)$.

The $P^{t i}($.$) function for labor income merits some elaboration; similar comments$ apply to the indirect tax function for sector $y$, or $P^{i i}($.$) . Following Thalmann (1992), we$ model the uncertainty associated with the tax evader's returns via first-order certainty equivalence around unreported income. Uncertainty is usually modeled by writing the optimization problem in expected utility. However, this approach has the disadvantage that it becomes somewhat intractable when the representative consumer has more choices than simply underreporting fixed income. Thalmann (1992) argues that an alternative approach is to use first-order certainty equivalence around the unreported income. In his approach, the actual income from unreported labor income is $\left[1-P^{t i}+e\right] w_{y} L_{y}^{i}$, where $e$ is a zeroexpectation stochastic variable. He shows that the solution of the maximization of expected utility is the same (to the first-order condition in $e$ ) as the solution to the problem in (1) and (2), where $e$ is replaced by its expected value. The expected penalty in this case is the

\footnotetext{
${ }^{16}$ We assume that taxes on corporate income are not levied on the informal sector firms since most informal sector firms are below the corporate income tax (CIT) threshold. For example, in Uganda firms with annual turnover of less than US $\$ 25,000$ are not subject to the CIT but rather are taxed via presumptive taxes. To the extent that the category of informal sector firms considered in our model are largely small- to medium-scale enterprises (e.g., with turnover less than US $\$ 25,000$ ), it is presumptive taxes rather than corporate income taxes that are evaded in the informal sector. Modeling of the evasion of presumptive taxes is left for future research.
} 
product of the probability of detection and the tax-plus-penalty rate charged on unreported income, and it increases at an increasing rate with enforcement parameters $\left(a^{t}\right)$ such as the frequency of audits and the penalty coefficient on regular tax rates and with the regular tax rate. Note that this approach requires either that the individual be risk neutral or that the stochastic component $e$ be close to zero; the latter restriction does not strictly occur unless the tax rate is also close to zero. ${ }^{17}$ Even so, the approach seems useful as a first approach to incorporating the individual evasion decision, and we follow the Thalmann (1992) approach in what follows.

\section{B. Firm Production Decisions}

Following Kehoe and Kehoe (1994), we assume that both goods have production functions that combine intermediate inputs in fixed proportions, and labor and capital with substitution possibilities governed by a Cobb-Douglas production function of the form $\beta k_{m}^{\alpha} I_{m}^{1-\alpha}$. Stated differently, goods are produced according to a nested Leontief-Cobb Douglas technology, where intermediate inputs and aggregate value-added enter at the top level. ${ }^{18}$ Value-added represents a Cobb-Douglas aggregation of labor and capital. The general form of the total production function of good $m$ is:

$$
q_{m}=\min \left(v_{x m} / a_{x m}, v_{y m} / a_{y m}, \beta k_{m}^{\alpha} I_{m}^{1-\alpha}\right), m=x, y .
$$

where

$v_{j m}$ is the intermediate input of good $j$ used in the production of good $m$ $a_{j m}$ is the amount of good $j$ required to produce one unit of good $m$ $a_{j m}, \beta_{m}$ and $\alpha_{m}$ are parameters to be calibrated.

\footnotetext{
17 We are grateful to Brian Erard for this observation.

18 The labor/capital elasticity in value-added is assumed to be 1, while the elasticity of substitution between intermediate inputs is assumed to be zero. Our choice of both the Cobb-Douglas structure for value-added and the Leontief intermediate input demand is standard in applied general equilibrium modeling.
} 
It is reasonable to expect that not every good is used in the production of every other good. This is corrected by dropping the corresponding entry from the production function. Producers are assumed to minimize costs and to earn zero after-tax profits. Given that this assumption implies that producers never waste inputs, the production function can be rewritten as:

$$
q_{m}=v_{x m} / a_{x m}=v_{y m} / a_{y m}=\beta_{m} k_{m}^{\alpha} I_{m}^{1-\alpha}
$$

Cost minimization further implies that $k_{m}$ and $I_{m}$ solve the problem:

$$
\min w_{m} I_{m}+r_{m} k_{m}
$$

subject to

$$
\beta_{m} k_{m}^{\alpha} l_{m}^{1-\alpha} \geq q_{m}
$$

where $w_{m}$ is the wage rate and $r_{m}$ is the capital rental rate. The assumption of zero after-tax profits implies that:

$$
\left(1-\tau_{m}\right) P_{m} q_{m}-\sum_{j=1}^{2} P_{j} a_{j m} q_{m}-w_{m} I_{m}-r_{m} k_{m}=0, m=x, y
$$

where $\tau_{m}$ is the indirect tax rate on the sales of good $m$.

\section{Equilibrium Conditions}

Mathiesen (1985) demonstrates that an Arrow-Debreu general economic equilibrium model can be formulated and solved as a complementarity problem. This problem can be depicted in terms of three sets of "central variables": $p$ is a non-negative $n$-vector of commodity prices including all final goods, intermediate goods, and primary factors of production; $y$ is a non-negative $m$-vector of activity levels for constant returns to scale production sectors in the economy; and $M$ is an $h$-vector of income levels, one for each "household" in the model, including any government entities. Equilibrium in these 
variables satisfies a system of three classes of nonlinear inequalities: zero profit, market clearance, and income balance. Consider each condition.

\section{Zero Profit}

The first class of constraints requires that in equilibrium no producer earns an "excess" profit; that is, the value of inputs per unit activity must be equal to or greater than the value of outputs. This can be written in compact form as:

$$
\operatorname{Cost}_{i}(p) \geq \operatorname{Re} \text { venue }_{i}(p) . \quad \perp y_{i}
$$

The corresponding complementary variable for a zero profit condition is output $y_{i}$. All else constant, if output prices increase for commodity $i$, then production activity increases until marginal cost equals marginal revenue.

\section{Market Clearance}

The second class of equilibrium conditions is that, at equilibrium prices and activity levels, the supply of any commodity must balance or exceed excess demand by consumers and producers. This condition can be expressed as:

$$
y_{i} \geq \sum_{i} \text { POOR }_{i}+\mathrm{RICH}_{i}+\mathrm{GOVT}_{i} . \quad \perp p_{i}
$$

Inequality (9) refers to produced commodities; a similar constraint holds for endowed goods such as labor and capital. The corresponding dual or complementary variable is the price $p_{i}$ (e.g., the price of both commodities and factors of production). Prices adjust until supply equals demand for a given commodity or factor.

\section{Income Balance}


The third condition is that in equilibrium the value of each agent's income must equal the value of labor and capital factor endowments, for POOR, RICH, and GOVT. Since we always work with utility functions that exhibit non-satiation, Walras' law always holds. In other words, complementary slackness, although not imposed as an equilibrium condition by itself, is a feature of the equilibrium allocation. This means that in equilibrium any production activity that is operated makes zero profit, while any production activity that earns a negative net return is idle. Similarly, any commodity that commands a positive price has a balance between aggregate supply and demand, and any commodity in excess supply has an equilibrium price of zero.

\section{MODEL CALIBRATION AND DATA}

This section describes our model calibration procedures. Our data do not represent any particular country, and have been chosen somewhat arbitrarily to reflect sectoral compositions in a "typical" developing country. We start with the Social Accounting Matrix (SAM), constructed under the assumption that the consumers and/or producers in the formal sector meet their tax obligations while their counterparts in the informal sector fully evade taxes (e.g., full compliance in the formal sector and tax evasion in the informal sector.) Table 1 presents a list of variable definitions, while Tables 2, 3, and 4 show the calibrated parameter values for the basic two-good, two-factor, and two-consumer closed economy models considered here. In all cases the model is constructed so that its initial equilibrium replicates the relevant benchmark data, before introducing a policy innovation (e.g., a change in a tax rate, a change in an expected penalty rate) and examining its distributional effects.

\section{A. Salient Features of the SAMs}


Table 2 summaries the salient features of the social accounting matrices used here.

These SAMs are constructed based on assumptions about the structure and size both of the formal and informal sectors and of the POOR and RICH households. We assume that the formal sector is more capital-intensive compared to the informal sector. We also assume that the informal sector utilizes part of the formal sector output (in addition to inputs of labor and capital) as an intermediate input in its production process, while the formal sector utilizes only capital and labor inputs in production. ${ }^{19}$ Finally, we assume that the POOR household's endowment is less than that of the RICH household; specifically, we assume that the POOR household's endowment is 33 percent of the endowment enjoyed by the RICH household, and we verify the robustness of our counterfactual results by changing this proportion to 25 and 50 percent. $^{20}$

Table 3 presents the calibrated parameter values for the basic two-good, two-factor, and two-consumer closed economy models, in which it is assumed that the RICH household only works in the formal sector and that the POOR household is only engaged in informal sector activities. Table 4 allows the RICH household to work in both the formal and informal sectors but the POOR household still works only in the informal sector. We now turn to a description of these data, focusing for the moment on Table 3.

\section{B. Taxes}

In the economy represented in Table 3, we assume that no taxes are levied in the benchmark equilibrium. Two tax treatments are introduced as counterfactual exercises:

\footnotetext{
19 An example of formal sector intermediate inputs used in the informal sector is a sweatshop producing handbags or wallets that utilize leather and thread from the formal sector.

20 Although the informal sector is present in all countries, its size in developing countries at times rivals that of the formal sector. The unweighted average of the shadow economy as a share of the official GDP in 2002/2003 was 43.2 percent in developing nations and 40.1 percent in East and Central European and former Soviet countries. For OECD countries, the unweighted average was 16.3 percent. See Schneider (2005).
} 
- There are commodity and income taxes in both sectors (e.g., there is full compliance in both sectors)

- There are commodity and income taxes in the formal sector but these taxes are imposed at zero rates in the informal sector (e.g., there is full compliance in the formal sector and complete tax evasion in the informal sector).

\section{Input/Output Data}

The input data are presented in the form of a balanced matrix, in which the entries represent the value of economic transactions in a given period, typically one year. The rectangular SAM format follows a sign convention wherein supplies or receipts are represented by positive numbers and demands or payments are represented by negative numbers. Internal consistency of a rectangular SAM implies that row sums and column sums are zero. With this interpretation, a row sum is zero if the total amount of commodity flowing into the economy equals the total amount of commodity flowing out of the economy. This represents market clearance, and one such condition applies for each commodity in the model. Columns in this matrix correspond to production sectors or consumers. A production sector column sum is zero if the value of outputs equals the cost of inputs. A consumer column is balanced if the sum of primary factor sales equals the value of final demands. Zero column sums thus indicate zero profits (product exhaustion) or consumer income balance.

In the SAM shown in Table 3, every market (e.g., traded commodity) has a row. There are four markets, for goods $x$ and $y$ and for factors labor and capital. (As discussed later under "Consumer Utility Functions", there are also separate rows for POOR and RICH household welfare, and for POOR and RICH household labor supply.) Again, there are two types of columns in a rectangular SAM, corresponding to production sectors and consumers. There are two production sectors $(x$ and $y)$ and three consumers (POOR, RICH, and GOVT). 
The numbers in the SAM are values, or prices multiplied by quantities. A commonly followed practice is to choose units so that the prices of as many activities as possible are initially equal to unity. However, in the presence of taxes, both consumer and producer prices generally cannot equal one.

\section{Production Sectors}

In Table 3, we assume that 110 units of output are produced in sector $x$ (the aboveground sector) using 50 units of labor and 60 units of capital. We also assume that sector $y$ (the underground sector) produces 100 units of output using 30 units of intermediate inputs from sector $x, 30$ units of labor, and 40 units of capital. These units are chosen to reflect the assumptions that production in sector $x$ uses more capital relative to all other production inputs compared to production in sector $y$, that sector $x$ does not utilize any intermediate inputs from sector $y$, and that sector $y$ utilizes less capital relative to all other production inputs compared to sector $X$. While it is possible to use diverse parameters to reflect these input and output choices, the choice of our input and output units is dictated by the need to maintain the internal consistency of our social accounting matrices or to preserve the zero profit, market clearing, and income balance conditions.

\section{E. Consumer Utility Functions}

The consumer's utility function is represented as a production activity, so that utility is a good that is produced from commodity inputs, including factor inputs such as leisure. The utility goods (PWP and PWR) are purchased using the consumer's endowments, which also reflect the income constraint. For example, in Table 3 the POOR consumer demands 50 units of utility good PWP, and receives 40 and 10 units of income from the endowments of labor and capital, respectively, to make this purchase. 
The activity level in sectors WP and WR (denoting the utility functions of POOR and RICH consumers, respectively) can also be interpreted as a Hicksian welfare index, the equivalent variation. Utility for the POOR consumer ( $\mathrm{WP}=50$ units) is "produced" using 5 units of good X, 35 units of good Y, and 10 units of leisure. Similarly, the RICH consumer's utility (WR $=150$ units) is produced using 75 units of good $x, 65$ units of good $y$, and 10 units of leisure. We assume that the POOR consumer's utility is intensive in the informal sector goods, while the RICH consumer's utility is intensive in the formal sector goods.

\section{F. Consumer Endowments and Labor Supplies}

We assume in Table 3 that the POOR consumer is endowed with 40 units of labor and 10 units of capital, while the RICH consumer is endowed with 60 units of labor and 90 units of capital. These choices reflect the assumption that the POOR consumer's total endowment is one-third of the RICH consumer's total endowment.

Table 3 also shows the labor supply choices of the three consumers (POOR, RICH, and GOVT). We allow a standard labor-leisure choice, in which labor chooses between leisure and labor supply with leisure entering into the workers utility function. In our formulation, we introduce additional activities TCONSP and TCONSR, which transform leisure (price PL) into labor supplied by the POOR and RICH households (price PLSP and PLSR, respectively). We assume that the POOR consumer owns 40 units of leisure, supplies 30 (PLSP) in the benchmark, and retains 10 as leisure. The RICH consumer is assumed to own 60 units of leisure, supplies 50 (PLSR) in the benchmark and retains 10 as leisure. In the presence of tax evasion, taxes are applied to both labor and capital supplied to the formal sector, and the leisure margin is untaxed. These units are chosen to emphasize the fact that the POOR consumer supplies less labor in the benchmark and thus enjoys more 
leisure compared to the RICH consumer. Specifically, the POOR household supplies 75 percent of the total leisure endowment and retains 25 percent as leisure. The RICH household supplies 83 percent of the total leisure endowment in the benchmark, and consumes the remaining 17 percent as leisure. Informal sector economic activity traditionally includes such activities as small plot-farming, street marketing, and other lowvolume activities (Light, 2004), and as such it seems reasonable to assume that the POOR consumer enjoys more leisure relative to total time endowment compared to the RICH consumer.

\section{G. Government}

The government (GOVT) is also considered as a separate consumer, which collects or demands tax revenues to provide a government good referred to as "public administration". Since no taxes are imposed and/or collected in the benchmark, the level of government activity is thus implicitly assumed to be zero in the benchmark. We assume that the government is the only consumer of this good, and consequently the RICH and POOR households do not enjoy any welfare from "public administration". Put differently, the government good does not enter the household utility functions, but increased government activity (or increased provision of the government good) increases the demand for labor and capital, so that the households earn wages and rents working for the government. We assume that production of the government good is labor-intensive. The government good is produced using formal sector labor $\left(L_{F}\right)$ and capital $(K)$ with substitution possibilities governed by a Cobb-Douglas production function, or $G=L_{F}^{\alpha_{F}} K^{\beta}$, in which constant returns to scale imply that $\alpha_{F}+\beta=1$. 


\section{H. Income Tax Evasion by the RICH Household}

The rectangular SAM presented in Table 3 assumes that the RICH household works only in the formal sector and consequently completely fulfills its labor income tax obligations. This SAM also is equivalent to assuming that only the POOR household engages in labor income tax evasion. (Recall, however, that both households may still be able to evade part of the legally due indirect tax obligations via consumption of informal sector output $y$.)

However, if the RICH household is allowed to supply labor to the informal sector, then it may be able to evade part of its legally due labor income tax payments. Table 4 presents the rectangular SAM for this scenario, where the RICH household works both in the formal and the informal sectors. The major difference between the choices presented in Tables 3 and 4 is that labor supplied by the RICH household to the informal sector $L_{y}^{1}$ is restricted to zero in Table 3, whereas labor supplied by the RICH household to the informal sector can be nonzero under the choices in Table $4 ;{ }^{21}$ that is, the consumption and production choices in Table 4 are similar to those in Table 3, except that the RICH consumer in Table 4 allocates only 80 percent of the labor supply (40 units) to the formal sector and the rest (10 units) is allocated to the informal sector. ${ }^{22}$

\section{Production/Consumption Functions and Elasticities}

\footnotetext{
${ }^{21}$ Note also that labor supplied by the POOR household to the formal sector (or $L_{x}^{2}$ in equation (2)) is restricted to zero under the scenarios presented in Tables 3 and 4, since we assume that the POOR household only works in the informal sector.

${ }^{22}$ We assume that the RICH consumer allocates only a fraction of labor supply to the informal sector, with the majority of the labor being supplied to the formal sector. Although there are various ways of modeling this labor supply decision, we assume that 40 units ( 80 percent of RICH household's labor supply) are allocated to the formal sector and 10 units ( 20 percent of the RICH household's labor supply) are allocated to the informal sector, so as to maintain the internal consistency of the SAM and also to preserve the zero profit, market clearing, and income balance conditions of our CGE model in Table 4.
} 
We adopt constant elasticity of substitution (CES) functions for producers and consumers because these functions are globally regular and can be defined by their zero, first, and second order properties. This implies that the location (price and quantity), slope (marginal rate of substitution), and curvature (convexity) completely characterize the function (Light, 2004).

We choose elasticities based largely on past studies and conventions (Light, 2004).

Specifically, we make the following elasticity assumptions:

- Labor/capital elasticity in value-added equals 1

- Elasticity of substitution between intermediate inputs equals 0

- Elasticity of substitution between goods $x$ and $y$ in final demand equals 1

- Labor-leisure elasticity equals 1

- Elasticity of substitutions (ESUB) between leisure and consumption equals 2.

Value-added in production represents a Cobb-Douglas aggregation of labor and capital, hence the labor/capital elasticity in value-added is 1 . The choice for the Leontief intermediate input demand is standard in CGE modeling. Finally, unity is chosen to be the elasticity between labor and leisure, and 2 is the default elasticity between leisure and consumption. The choice for the elasticity between leisure and consumption is motivated by the need to model perfect competition in the informal sector of the economy.

\section{J. Consumer Welfare Changes}

A widely used measure of welfare change is how much income the consumer would require, when faced with base case prices, to achieve the same level of utility as in the simulation, or the equivalent variation. We use this measure of consumer welfare change to compare the welfare gains and/or losses accruing to the POOR and RICH households.

\section{K. Sensitivity Analyses}


Various sensitivity analyses are performed to verify the consistency and robustness

of our results. One set examines the assumptions about the relative endowment of the

POOR household. As one variation here, we assume that the total endowment of the POOR

household is only 25 percent of the endowment enjoyed by RICH household; in another, we assume that the POOR household's total endowment is 50 percent of the RICH household's total endowment. The SAMs in Tables 3 and 4 are adjusted accordingly. ${ }^{23}$

${ }^{23}$ For example, with full compliance in the formal sector and a POOR household endowment of 25 percent of a RICH household endowment, the SAM becomes:

\begin{tabular}{|l|cccccc|cc|}
\hline & \multicolumn{7}{|c|}{ Production Sectors } & \multicolumn{2}{c|}{ Consumer Endowments } \\
\cline { 2 - 9 } Markets & $\mathrm{X}$ & $\mathrm{Y}$ & WP & WR & TC ONSP & TC ONSR & POOR & RICH \\
\hline PX & 155 & -30 & -5 & -120 & & & & \\
PY & & 100 & -35 & -65 & & & -50 & \\
PWP & & & 50 & & & & & -200 \\
PWR & & & & 200 & & & & \\
PLSP & & -30 & & & 30 & & & \\
PLSR & -70 & & & & & 70 & & \\
PL & & & -10 & -15 & -30 & -70 & & 115 \\
PK & -85 & -40 & & & & & & \\
\hline
\end{tabular}

Here the POOR consumer has a total endowment of 40 units of labor in the benchmark, supplies 75 percent of this labor endowment ( 30 units) to be used in the production process, and retains 25 percent (10 units) as leisure. The RICH household has a total endowment of 85 units of labor in the benchmark, supplies 82 percent of this labor endowment (70 units) to the production process, and retains 18 percent (15 units) as leisure. We maintain the assumption that the relatively inefficient nature of production in the informal sector $y$ implies that the POOR household is able to devote a higher percentage of the labor endowment to leisure compared to the RICH household. The output units in also reflect the fact that production is more efficient and capitalintensive in the formal sector relative to the informal sector. With partial compliance in the formal sector and a POOR household endowment of 25 percent of a RICH household endowment, the SAM becomes:

\begin{tabular}{|l|cccccc|cc|}
\hline & \multicolumn{6}{|c|}{ Production Sectors } & \multicolumn{2}{c|}{ Consumer Endowments } \\
\cline { 2 - 9 } Markets & $\mathrm{X}$ & $\mathrm{Y}$ & WP & WR & TC ONSP & TC ONSR & POOR & RICH \\
\hline PX & 155 & -30 & -5 & -120 & & & & \\
PY & & 100 & -35 & -65 & & & -50 & \\
PWP & & & 50 & & & & & -200 \\
PWR & & & & 200 & & & & \\
PLSP & & -30 & & & 30 & & & \\
PLSR & -56 & -14 & & & & 70 & 10 & 115 \\
PL & & & -10 & -15 & -30 & -70 & & \\
PK & -99 & -26 & & & & & & \\
\hline
\end{tabular}

Now the RICH consumer allocates 80 percent of the labor endowment (56 units) to the formal sector and the rest (14 units) to the informal sector. Similar adjustments are made to the SAMs for a POOR household endowment of 50 percent of a RICH household endowment under full or partial compliance. 
Another set changes the expected penalty rates in these different scenarios. Still another set varies the elasticity assumptions, especially the elasticity of substitution between leisure and consumption, in order to examine the impact of different degrees of mobility between the sectors upon our results. A final set changes the tax rates on consumption and income. As discussed later, our main results are largely unaffected.

\section{SIMULUATIONS}

Analysis of the impact of a change in government policy proceeds via the comparative statics methodology. As noted earlier, the model is constructed so that its equilibrium replicates the benchmark data. Simulation of the policy change then follows by altering the relevant policy parameters (say, a change in the ad valorem tax rate on good $m$, or $\tau_{m}$ ) and calculating the new equilibrium. In the base case equilibrium, prices $P_{m}$, the wage $W$, and the capital rental rate $r$ are all calibrated to equal one. The model is then used to evaluate the impact of changes in government policy on the welfare of the POOR and RICH households, on consumption, and on the prices of produced goods and factors of production. $^{24}$ Our model allows for varying degrees of mobility into and out of the informal sector, mainly by varying the elasticity of substitution between leisure and consumption, in order to measure how much of the initial tax advantage is retained by the evaders and how much is competed away via factor and commodity prices changes. The main purpose of our counterfactual exercises is to compare the initial to the final post-evasion/post-tax equilibria, under the various scenarios (especially when the RICH household works only in the informal sector and when it allocates some of its labor to the informal sector); that is, how much of the initial gain from tax evasion (e.g., the gain that does not consider factor

\footnotetext{
${ }^{24}$ An alternative approach is to begin with a benchmark equilibrium where taxes are imposed but where there is no tax evasion. The counterfactual could comprise introducing tax evasion and then comparing welfare across various groups for the two equilibria. This approach awaits further research.
} 
and commodity price changes in response to tax evasion) is retained by income tax evaders and how much is dissipated via general equilibrium adjustments in prices? ${ }^{25}$ A discussion of our simulation results follows.

\section{A. RICH Household Works Only in the Formal Sector}

We first analyze the general equilibrium effects when the RICH household works only in the formal sector, using the benchmark data presented in Table 3. We levy an advalorem commodity tax at a 10 percent rate and an income tax at a proportional rate of 25 percent. All counterfactual results incorporate an equal-yield tax constraint in the formal sector and a labor-leisure choice in both the formal and informal sectors.

Table 5 presents a summary of the general equilibrium effects resulting both from the evasion of commodity taxes in the informal sector by both POOR and RICH households, and from the evasion of income taxes in the informal sector by the POOR household only. Using changes in consumer welfare as an overall indicator of the gains and/or losses from tax evasion, the top part of Table 5 indicates that the POOR household initially benefits from evasion but only somewhat. This initial gain is computed using the default elasticity of substitution between leisure and consumption, or 2. To simulate longrun entry into the informal sector, we then increase this elasticity to $8 .^{26}$ In our simulations of the initial and long-run effects, we adjust the tax rates in the formal sector so that overall government revenue is maintained at the full compliance (in the absence of tax evasion) equilibrium level. We find that the initial benefit of evasion for the POOR household dissipates as entry into the informal sector expands. Specifically, Table 5 shows that the

\footnotetext{
${ }^{25}$ Recall that in all scenarios considered here the POOR household works only in the informal sector.

26 "Initial" refers to the outcome with limited competition and/or entry in the informal sector. "Final" refers to the outcome with increased competition and/or entry in the informal sector. The elasticity of substitution between leisure and consumption is increased from 2 to 8 to depict the increased competition and/ or entry in the informal sector. Increasing this elasticity to parameter values exceeding 8 does not change the interpretation of our results.
} 
POOR household retains 78.2 percent of the initial 2.4 percent increase in its welfare, while 21.8 percent of this initial gain in welfare is eliminated as a result of entry into the informal sector. $^{27}$ The RICH household's welfare initially falls by 0.64 percent, but mobility reduces this loss to only -0.02 percent, which represents a 96.9 percent increase in welfare for the RICH household arising from mobility into the informal sector. The increase in the RICH household's commodity $X$-intensive welfare is mainly attributed to a reduction in the taxinclusive price of commodity $X$ as mobility into the informal sector occurs.

Table 5 also shows that the tax-inclusive price of commodity $x$ falls by 8.6 percent with mobility into the informal sector, while the price of good $y$ increases by 9.8 percent. The POOR household's welfare is intensive in commodity $y$, and so an increase in the commodity price of good $y$ reduces the POOR household's welfare. Further, mobility increases the amount of labor supplied by the POOR and RICH households by 59.8 percent and 122.6 percent, respectively, leading to a reduction in their net-of-tax wages by 13.4 percent and 184.0 percent, respectively.

Increasing the expected penalty rate only alters the size of these changes and not their direction. The lower part of Table 5 shows that with the increased expected penalty rates the initial increase in the POOR household's welfare is only 1.08 percent. Now the POOR household keeps just 76.8 percent of this increase in welfare, while 23.2 percent is competed away with mobility, and the RICH household experiences a 112.0 percent increase in welfare with mobility. Increased expected penalty rates for evasion (and increased entry/competition into the informal sector) therefore work toward the elimination of the differences in factor prices, commodity prices, and consumer welfare in the formal and informal sectors. Perhaps surprisingly, the increased penalty rate leads to a final level of welfare that is actually higher for both RICH and POOR households than the level of

\footnotetext{
${ }^{27}$ The "initial" gain or loss refers to the percentage change between the post-evasion and post-tax welfare.
} 
welfare achieved in the absence of tax evasion. ${ }^{28}$ This result illustrates that evasion can alleviate some of the labor market distortions associated with taxation, especially when a high expected penalty rate generates large potential distortions.

\section{B. RICH Household Allocates Some Labor to the Informal Sector}

Recall that we also allow the RICH household to allocate some of its labor to the informal sector, using the SAM in Table 4. This scenario allows the RICH household to evade some of its labor income tax liabilities by working in the informal sector. The RICH household allocates labor between the formal and informal sectors by comparing the statutory tax rate with the expected penalty for evasion, respectively (or the relative wages in these two sectors). All counterfactual results again incorporate an equal-yield tax constraint in the formal sector and a labor-leisure choice in both formal and informal sectors. The initial equilibrium change when evasion is introduced is based on the default value of 2 for the elasticity of substitution between leisure and consumption, while the final equilibrium under greater mobility is simulated by setting this parameter equal to 8 . The results are presented in Table 6.

The effects on commodity prices, price of capital, and welfare for both the POOR and RICH household mimic those in Table 5. For example, the POOR household retains 77.2 percent of the initial 2.8 percent increase in its welfare, while 22.7 percent of this initial gain in welfare is eliminated as a result of mobility by both POOR and RICH into the informal sector. The RICH household's welfare initially falls by 0.76 percent, but mobility reduces this loss to only -0.05 percent, representing a 106.5 percent increase in welfare for the RICH household. However, although the amount of labor supplied by RICH household

\footnotetext{
${ }^{28}$ It should be noted that this welfare calculation does not include benefits from government spending, for instance, by providing public goods that would otherwise be underprovided in the presence of tax evasion.
} 
increases by 233.1 percent (which is 110.5 percentage points higher than in Table 5), the results in Table 6 indicate that the net-of-tax wage for the RICH household falls by 126.8 percent (or 57.2 percentage points less than in Table 5). This result occurs because the RICH household is now able to supply labor to the informal sector and so can evade the income tax on those labor earnings; this adjustment mitigates the reduction in the net-of-tax wage for the RICH household, but also exacerbates the reduction in the net-of-tax wage for the POOR household. Also, as with some of the results in Table 5, we again see that evasion may reduce some of the distorting effects of taxation, since the post-evasion welfare actually increases for both RICH and POOR households.

\section{Sensitivity Analysis: Changing the Endowments of POOR and RICH Households}

Some additional sensitivity analyses are based on alternative SAMs, in which the endowments of POOR and RICH households are adjusted. Overall, the sensitivity results show that variations in the proportion of the POOR household's endowment to that of the RICH household does not affect our results in any significant way. For example, in Tables 7 and 8 the POOR household's endowment is 25 percent of the RICH household's endowment.

The results in Table 7 (with the RICH household working only in the formal sector) indicate that the POOR household's post-evasion welfare is only 3.01 percent higher than the post-tax welfare if it had fully complied with taxes. Further, the POOR household keeps 77.1 percent of this initial increase in welfare, while 22.9 percent of this initial gain is competed away as a result of mobility into the informal sector. The RICH household's welfare initially falls by 0.58 percent, but mobility results in a 0.01 percent increase in the RICH household's welfare, representing a gain of 101.7 percent. The increase in the RICH household's commodity $X$-intensive welfare is due to a reduction in the tax-inclusive price 
of commodity $x$ as mobility into the informal sector occurs. Increasing the expected penalty rate for evasion does not alter these general results.

Similarly, the results in Table 8 (with the RICH household allocating some of its labor to the informal sector, where labor income tax evasion is possible) show that the taxinclusive price of commodity $x$ falls by 3.8 percent with mobility, while the commodity price of good $y$ increases by 6.5 percent. The POOR household's welfare is intensive in commodity $y$, and an increase in the price of commodity $y$ leads to a reduction in the POOR household's welfare. Further, increased competition from the informal sector leads to an increase in the amount of labor supplied in the informal and formal sectors by 88.4 percent and 363.1 percent, respectively, leading to a reduction in the net-of-tax wages by 30.3 percent and 75.2 percent, respectively. As with our earlier results, the POOR household benefits only marginally from tax evasion, and this advantage diminishes with entry and competition in the informal sector. Increasing the expected penalty rate for evasion does not change these conclusions.

When we assume that the POOR household's endowment is 50 percent of the RICH household's endowment, the results are also consistent with the results in Tables 5 to 8 . Similarly, other sensitivity results for variations in the elasticity of substitution between leisure and consumption and for different levels of the commodity and income tax rates are very similar to the results that we report. These results are not reported, but are available upon request.

\section{CONCLUSIONS}

Distributional conclusions drawn from the standard approach to tax evasion are unsatisfactory because this approach ignores the fact that tax evasion is much like a "tax advantage" in the law, so that replication and competition should work toward the 
elimination of this advantage. This process of adjustment takes place through changes in the relative prices of both commodities and factors of production, as mobility occurs into and out of the relevant sectors. The standard approach takes only a partial equilibrium perspective, and does not capture these general equilibrium mobility effects.

Our approach addresses this limitation by utilizing a CGE model to analyze the incidence of tax evasion. We assume that there are two broadly defined sectors of the economy, the formal sector where labor income is taxed and the informal sector where labor income is untaxed. We adapt our model and specifications to characterize the circumstances of a "typical" developing country.

The counterfactual experiments indicate that the tax evader does not benefit exclusively from evasion. Indeed, our results indicate that any "tax advantage" from evasion diminishes with mobility into the informal sector, as well as with an increase in the expected penalty associated with tax evasion. The evading household benefits but only somewhat from tax evasion, and this advantage shrinks significantly with mobility. Additionally, both the net-of-tax wage for informal sector labor and the consumer price of the informal sector output decline with tax-evasion-induced mobility. We also find that there are some circumstances under which tax evasion actually increases the welfare of all households, as evasion reduces some of the distorting effects of taxation.

In short, the gains from evasion are shifted at least in part from the evaders to the consumers of their output via lower prices, as general equilibrium mobility effects work via relative price and productivity changes to eliminate the incentive for workers to enter the informal sector beyond some margin. As more workers enter the underground sector, their production pushes down the relative price of the informal sector output and consequently the hourly returns of working in there; the movement of workers between the sectors also changes the relative productivity of workers in each sector as capital also moves between 
the sectors. In equilibrium, therefore, the marginal entrant to the informal sector has the gains from evading taxes offset by the relative price and productivity effects. ${ }^{29}$

There are many possible extensions to this work. An obvious extension is to experiment with a somewhat lower expected tax plus penalty rate; the (relatively) small initial welfare effects for POOR households likely occurs because this rate is only slightly lower than the tax rate in the formal sector. Another obvious extension is to conduct additional sensitivity analyses, including further examination of, say, the roles played by the intermediate good, the relative size of the informal sector, and relative factor intensities.

Finally, the underlying framework could be generalized to consider greater taxpayer heterogeneity, a broader range of government activities, the impact of open economy considerations, the potential for government corruption, and dynamic incidence factors. The most important extension here is to incorporate fully expected utility. Finally, it would be interesting to examine whether traditional "tax equivalence" results still hold in the presence of tax evasion, such as the (presumed) equivalence between a proportional income tax and a proportional consumption tax (with an equal rate on all commodities). These extensions await future work.

\section{ACKNOWLEDGEMENTS}

An earlier version of this paper was presented at the "Mobility and Tax Policy Conference", held at the University of Tennessee at Knoxville in October 2008. We are grateful to conference participants for many helpful suggestions, especially to Brian Erard for his many detailed and insightful comments. We also benefitted from the suggestions of two referees and the editor, William Fox.

\section{REFERENCES}

\footnotetext{
29 There could also be changes in the "psychic costs" associated with working in the informal sector. Psychic costs reflect the distaste that individuals experience when working in each sector, which includes innate preferences for each type of work as well as the possible loss of status and fear of apprehension associated with working in the underground sector (Kesselman, 1989).
} 
Allingham, Michael G., and Agnar Sandmo, 1972.

"Income Tax Evasion: A Theoretical Analysis." Journal of Public Economics 1 (3-4), 323338.

Alm, James, 1985.

"The Welfare Cost of the Underground Economy." Economic Inquiry 23 (2), 243-263.

Alm, James, Roy Bahl, and Matthew N. Murray, 1991.

"Tax Base Erosion in Developing Countries." Economic Development and Cultural

Change 39 (4), 849-872.

Davidson, Carl, Lawrence Martin, and John Douglas Wilson, 2007.

"Efficient Black Markets?" Journal of Public Economics 91 (7-8), 1575-1590.

Harberger, Arnold C., 1962.

"The Incidence of the Corporate Income Tax." The Journal of Political Economy 70 (3), 215-240.

Jung, Young H., Arthur Snow, and Gregory A. Trandel, 1994.

"Tax Evasion and the Size of the Underground Economy." Journal of Public Economics 54 (3), 391-402.

Kehoe, Patrick J., and Timothy J. Kehoe, 1994.

"A Primer on Static Applied General Equilibrium Models." Federal Reserve Bank of Minneapolis Quarterly Review 18 (1), 2-16.

Kehoe, Timothy J., and Jaime Serra-Puche. 1983.

"A Computational General Equilibrium Model with Endogenous Unemployment: An Analysis of the 1980 Fiscal Reform in Mexico." Journal of Public Economics 22 (1), 1-26.

Kesselman, Jonathan R., 1989.

"Income Tax Evasion: An Intersectoral Analysis." Journal of Public Economics 38 (2), 137-182.

Light, Miles, 2004.

"Taxation and Economic Efficiency in Jamaica." International Studies Program Working Paper, Andrew Young School of Policy Studies, Georgia State University, Atlanta, GA.

Martinez-Vazquez, Jorge, 1996.

"Who Benefits from Tax Evasion? The Incidence of Tax Evasion." Public Economics Review 1 (2), 105-135.

Mathiesen, Lars, 1985.

"Computation of Economic Equilibria by a Sequence of Linear Complementarity Problems." In Alan S. Manne (ed.), Mathematical Programming Study 23 - Economic Equilibrium: Model Formulation and Solution, 144-162. North-Holland, Amsterdam, The Netherlands.

Nguyen, Trien T., and John Whalley, 1989. 
"General Equilibrium Analysis of Black and White Markets: A Computational Approach." Journal of Public Economics 40 (3), 331-347.

Persson, Mats, and Pehr Wissen, 1984.

"Redistributional Aspects of Tax Evasion." Scandinavian Journal of Economics 86 (2), 131 149.

Schneider, Friedrich, 2005.

"Shadow Economies around the World: What Do We Really Know?" European Journal of Political Economy 21 (3), 598-642.

Sennoga, Edward B., 2005.

Essays on Tax Evasion. Ph.D. Dissertation, Andrew Young School of Policy Studies, Georgia State University, Atlanta, GA.

Shah, Anwar, and John Whalley, 1990.

"An Alternative View of Tax Incidence Analysis for Developing Countries." NBER Working Paper No. 3375. National Bureau of Economic Research, Cambridge, MA.

Skinner, Jonathan, and Joel Slemrod, 1985.

"An Economic Perspective on Tax Evasion." National Tax Journa/ 38 (3), 345-353.

Thalmann, Philippe, 1992.

"Factor Taxes and Evasion in General Equilibrium." Regional Science and Urban Economics 22 (2), 259-283.

Watson, Harry, 1985.

"Tax Evasion and Labor Markets." Journal of Public Economics 27 (2), 231-246. 
Table 1

List of Variable Definitions

\begin{tabular}{|l|l|}
\hline X & Activity level for formal or taxed sector X \\
\hline Y & Activity level for informal or untaxed sector Y \\
\hline TX & Ad-valorem tax rate for X sector inputs \\
\hline TY & Ad-valorem tax rate for Y sector inputs \\
\hline TXI & Proportional tax rate on X sector inputs \\
\hline TYI & Proportional tax rate on Y sector inputs \\
\hline POOR & Evading (informal) household \\
\hline RICH & Conforming (formal) household \\
\hline WP & Hicksian welfare function for informal (POOR) household \\
\hline WR & Hicksian welfare function for formal (RICH) household \\
\hline G & Government activity level, equal to zero in benchmark \\
\hline TCONSR & Labor supply for formal (RICH) household \\
\hline TCONSP & Labor supply for informal (POOR) household \\
\hline PX & Price index for commodity X \\
\hline PY & Price index for commodity Y \\
\hline PL & Price index for primary factor L \\
\hline PK & Price index for primary factor K \\
\hline PWP & Price index for POOR household welfare \\
\hline PWR & Price index for RICH household welfare \\
\hline PG & Price index for the government good (e.g., cost of administration) \\
\hline PLSP & Price index for POOR household labor supply \\
\hline PLSR & Price index for RICH household labor supply \\
\hline GOVT & Government (e.g., tax collector) \\
\hline ESUB & Elasticity of substitution between leisure and consumption \\
\hline
\end{tabular}

Table 2

Social Accounting Matrix: Summary of Salient Features

\begin{tabular}{|c|c|c|}
\hline Markets & Production Sectors & Consumer Endowments \\
\hline Good X & $\begin{array}{l}\circ \mathrm{X} \text { uses more capital relative to all other inputs } \\
\text { in production } \\
\circ \mathrm{X} \text { uses only inputs of capital and labor } \\
\circ \mathrm{RICH} \text { welfare is X-intensive }\end{array}$ & \multirow{4}{*}{$\begin{array}{c}\text { POOR has } 25 \text { percent of } \\
\text { RICH endowment } \\
\circ \text { POOR has } 33 \text { percent of } \\
\text { RICH endowment } \\
\circ \text { POOR has } 50 \text { percent of } \\
\text { RICH endowment }\end{array}$} \\
\hline Good Y & $\begin{array}{l}\text { O Y uses more labor relative to all other inputs } \\
\text { in production } \\
\text { O Y uses capital and labor inputs plus } \\
\text { intermediate inputs from X } \\
\text { POOR welfare is Y-intensive }\end{array}$ & \\
\hline Capital & $\begin{array}{l}\mathrm{X} \text { uses more capital relative to all other inputs } \\
\text { in production }\end{array}$ & \\
\hline Labor & $\begin{array}{l}\text { O Y uses more labor relative to all other inputs } \\
\text { in production } \\
\text { POOR enjoys more leisure relative to RICH }\end{array}$ & \\
\hline
\end{tabular}


Table 3

Social Accounting Matrix: Labor-leisure Choice and Intermediate Inputs in Production with RICH Household Operating Only in Formal Sector and with POOR Household Endowment 33

Percent of RICH Household Endowment

\begin{tabular}{|l|cccccc|cc|}
\hline & \multicolumn{7}{|c|}{ Production Sectors } & \multicolumn{2}{c|}{ Consumer Endowments } \\
\cline { 2 - 8 } Markets & X & Y & WP & WR & TCONSP & TCONSR & POOR & RICH \\
\hline PX & 110 & -30 & -5 & -75 & & & & \\
PY & & 100 & -35 & -65 & & & -50 & \\
PWP & & & 50 & & & & & -150 \\
PWR & & & & 150 & & & & \\
PLSP & & -30 & & & 30 & 50 & & \\
PLSR & -50 & & & & & -50 & 40 & 60 \\
PL & & & -10 & -10 & -30 & -50 & \\
PK & -60 & -40 & & & & & 10 & 90 \\
\hline
\end{tabular}

Note. The actual values in the Social Accounting Matrix reflect three internal consistency conditions: zero profit, market clearing, and income balance.

Table 4

Social Accounting Matrix: Labor-leisure Choice and Intermediate Inputs in Production with RICH Household Allocating Some Labor to Informal Sector and with POOR Household Endowment 33 Percent of RICH Household Endowment

\begin{tabular}{|l|cccccc|cc|}
\hline & \multicolumn{7}{|c|}{ Production Sectors } & \multicolumn{2}{c|}{ Consumer Endowments } \\
\cline { 2 - 8 } Markets & X & Y & WP & WR & TCONSP & TCONSR & POOR & RICH \\
\hline PX & 110 & -30 & -5 & -75 & & & & \\
PY & & 100 & -35 & -65 & & & -50 & \\
PWP & & & 50 & & & & & -150 \\
PWR & & & & 150 & & & & \\
PLSP & & -30 & & & 30 & & & \\
PLSR & -40 & -10 & & & & 50 & & \\
PL & & & -10 & -10 & -30 & -50 & 40 & 90 \\
PK & -70 & -30 & & & & & 10 & 90 \\
\hline
\end{tabular}

Note. The actual values in the Social Accounting Matrix reflect three internal consistency conditions: zero profit, market clearing, and income balance. 
Table 5

Summary of General Equilibrium Effects: RICH Household Works Only in Formal Sector and POOR Household Endowment Is 33 Percent of RICH Household Endowment

\begin{tabular}{|c|c|c|c|c|}
\hline \multicolumn{5}{|c|}{$\begin{array}{l}\text { Statutory ad valorem commodity tax }=0.1, \text { Statutory proportional income tax rate }=0.25 \\
\text { Expected penalty rate (commodity taxes) }=0.07 \text {, Expected penalty rate (income taxes) }=0.2\end{array}$} \\
\hline & \multicolumn{2}{|c|}{ POOR Household } & \multicolumn{2}{|c|}{ RICH Household } \\
\hline & $\begin{array}{l}\text { Magnitude } \\
(\%)\end{array}$ & $\begin{array}{l}\text { Percent Change } \\
(\%)\end{array}$ & $\begin{array}{l}\text { Magnitude } \\
(\%)\end{array}$ & $\begin{array}{l}\text { Percent Change } \\
(\%)\end{array}$ \\
\hline Initial Post-Evasion Welfare & 2.43 & \multirow[b]{2}{*}{-21.8} & -0.64 & \multirow[b]{2}{*}{96.9} \\
\hline Final Post-Evasion Welfare & 1.90 & & -0.02 & \\
\hline Initial Price of Good X & 5.99 & \multirow[b]{2}{*}{-8.6} & 5.99 & \multirow[b]{2}{*}{-8.6} \\
\hline Final Price of Good X & 5.47 & & 5.47 & \\
\hline Initial Price of Good Y & -6.30 & \multirow[b]{2}{*}{9.8} & -6.30 & \multirow[b]{2}{*}{9.8} \\
\hline Final Price of Good Y & -5.68 & & -5.68 & \\
\hline Initial Post-Evasion Rental Rate & -0.89 & \multirow[b]{2}{*}{365.1} & -0.89 & \multirow[b]{2}{*}{365.1} \\
\hline Final Post-Evasion Rental Rate & 2.36 & & 2.36 & \\
\hline Initial Post-Evasion Net Wage & -4.02 & \multirow[b]{2}{*}{-13.4} & 0.50 & \multirow[b]{2}{*}{-184.0} \\
\hline Final Post-Evasion Net Wage & -4.56 & & -0.87 & \\
\hline Initial Post-Evasion Labor Supply & 6.43 & \multirow[b]{2}{*}{59.8} & -2.74 & \multirow[b]{2}{*}{122.6} \\
\hline Final Post-Evasion Labor Supply & 10.28 & & 0.62 & \\
\hline \multicolumn{5}{|c|}{$\begin{array}{l}\text { Statutory ad valorem commodity tax }=0.1 \text {, Statutory proportional income tax rate }=0.25 \\
\text { Expected penalty rate (commodity taxes) }=0.095 \text {, Expected penalty rate (income taxes) }=0.225\end{array}$} \\
\hline Initial Post-Evasion Welfare & 1.08 & \multirow[b]{2}{*}{-23.2} & -0.25 & \multirow[b]{2}{*}{112.0} \\
\hline Final Post-Evasion Welfare & 0.83 & & 0.03 & \\
\hline Initial Price of Good X & 2.56 & \multirow[b]{2}{*}{-9.4} & 2.56 & \multirow[b]{2}{*}{-9.4} \\
\hline Final Price of Good X & 2.32 & & 2.32 & \\
\hline Initial Price of Good Y & -2.79 & \multirow[b]{2}{*}{10.8} & -2.79 & \multirow[b]{2}{*}{10.8} \\
\hline Final Price of Good Y & -2.49 & & -2.49 & \\
\hline Initial Post-Evasion Rental Rate & -0.37 & \multirow[b]{2}{*}{405.4} & -0.37 & \multirow[b]{2}{*}{405.4} \\
\hline Final Post-Evasion Rental Rate & 1.13 & & 1.13 & \\
\hline Initial Post-Evasion Net Wage & -0.99 & \multirow[b]{2}{*}{-25.2} & 0.60 & \multirow[b]{2}{*}{-160.0} \\
\hline Final Post-Evasion Net Wage & -1.24 & & -0.36 & \\
\hline Initial Post-Evasion Labor Supply & 2.80 & \multirow[b]{2}{*}{59.6} & -1.18 & \multirow[b]{2}{*}{130.5} \\
\hline Final Post-Evasion Labor Supply & 4.47 & & 0.36 & \\
\hline
\end{tabular}

Note. "Initial" refers to the outcome with limited competition and/or entry in the informal sector. "Final" refers to the outcome with increased competition and/or entry in the informal sector. "Magnitude" is the percentage difference between the post-evasion and post-tax outcome if both POOR and RICH households complied with taxes. "Percent change" refers to the percentage change between the magnitude for the "initial" and "final" outcome. 
Table 6

Summary of General Equilibrium Effects: RICH Household Allocates Some Labor to Informal Sector and POOR Household Endowment Is 33 Percent of RICH Household

Endowment

\begin{tabular}{|c|c|c|c|c|}
\hline \multicolumn{5}{|c|}{$\begin{array}{l}\text { Statutory ad valorem commodity tax }=0.1 \text {, Statutory proportional income tax rate }=0.25 \\
\text { Expected penalty rate (commodity taxes) }=0.07 \text {, Expected penalty rate (income taxes) }=0.2\end{array}$} \\
\hline & \multicolumn{2}{|c|}{ POOR Household } & \multicolumn{2}{|c|}{ RICH Household } \\
\hline & $\begin{array}{l}\text { Magnitude } \\
(\%)\end{array}$ & $\begin{array}{l}\text { Percent Change } \\
(\%)\end{array}$ & $\begin{array}{l}\text { Magnitude } \\
(\%)\end{array}$ & $\begin{array}{c}\text { Percent Change } \\
(\%)\end{array}$ \\
\hline Initial Post-Evasion Welfare & 2.81 & \multirow[b]{2}{*}{-22.7} & -0.76 & \multirow[b]{2}{*}{106.5} \\
\hline Final Post-Evasion Welfare & 2.17 & & 0.05 & \\
\hline Initial Price of Good X & 6.24 & \multirow[b]{2}{*}{-6.5} & 6.24 & \multirow[b]{2}{*}{-6.5} \\
\hline Final Price of Good X & 5.83 & & 5.83 & \\
\hline Initial Price of Good Y & -6.65 & \multirow[b]{2}{*}{8.1} & -6.65 & \multirow[b]{2}{*}{8.1} \\
\hline Final Price of Good Y & -6.11 & & -6.11 & \\
\hline Initial Post-Evasion Rental Rate & -1.68 & \multirow[b]{2}{*}{229.7} & -1.68 & \multirow[b]{2}{*}{229.7} \\
\hline Final Post-Evasion Rental Rate & 2.18 & & 2.18 & \\
\hline Initial Post-Evasion Net Wage & -3.37 & \multirow[b]{2}{*}{-24.6} & -0.67 & \multirow[b]{2}{*}{-126.8} \\
\hline Final Post-Evasion Net Wage & -4.20 & & -1.52 & \\
\hline Initial Post-Evasion Labor Supply & 6.02 & \multirow[b]{2}{*}{81.0} & -2.05 & \multirow[b]{2}{*}{233.1} \\
\hline Final Post-Evasion Labor Supply & 10.90 & & 2.73 & \\
\hline \multicolumn{5}{|c|}{$\begin{array}{c}\text { Statutory ad valorem commodity tax }=0.1 \text {, Statutory proportional income tax rate }=0.25 \\
\text { Expected penalty rate (commodity taxes) }=0.095 \text {, Expected penalty rate (income taxes) }=0.225\end{array}$} \\
\hline Initial Post-Evasion Welfare & 1.23 & \multirow[b]{2}{*}{-24.3} & -0.29 & \multirow[b]{2}{*}{124.1} \\
\hline Final Post-Evasion Welfare & 0.93 & & 0.07 & \\
\hline Initial Price of Good X & 2.64 & \multirow[b]{2}{*}{-7.1} & 2.64 & \multirow[b]{2}{*}{-7.1} \\
\hline Final Price of Good X & 2.45 & & 2.45 & \\
\hline Initial Price of Good Y & -2.93 & \multirow[b]{2}{*}{9.2} & -2.93 & \multirow[b]{2}{*}{9.2} \\
\hline Final Price of Good Y & -2.66 & & -2.66 & \\
\hline Initial Post-Evasion Rental Rate & -0.67 & \multirow[b]{2}{*}{259.7} & -0.67 & \multirow[b]{2}{*}{259.7} \\
\hline Final Post-Evasion Rental Rate & 1.07 & & 1.07 & \\
\hline Initial Post-Evasion Net Wage & -0.69 & \multirow[b]{2}{*}{-81.9} & -0.24 & \multirow[b]{2}{*}{-158.3} \\
\hline Final Post-Evasion Net Wage & -1.08 & & -0.62 & \\
\hline Initial Post-Evasion Labor Supply & 2.62 & \multirow[b]{2}{*}{80.1} & -0.88 & \multirow[b]{2}{*}{245.5} \\
\hline Final Post-Evasion Labor Supply & 4.72 & & 1.28 & \\
\hline
\end{tabular}

Note. "Initial" refers to the outcome with limited competition and/or entry in the informal sector. "Final" refers to the outcome with increased competition and/or entry in the informal sector. "Magnitude" is the percentage difference between the post-evasion and post-tax outcome if both POOR and RICH households complied with taxes. "Percent change" refers to the percentage change between the magnitude for the "initial" and "final" outcome. 
Table 7

Summary of General Equilibrium Effects: RICH Household Works Only in Formal Sector and POOR Household Endowment Is 25 Percent of RICH Household Endowment

\begin{tabular}{|c|c|c|c|c|}
\hline \multicolumn{5}{|c|}{$\begin{array}{l}\text { Statutory ad valorem commodity tax }=0.1 \text {, Statutory proportional income tax rate }=0.25 \\
\text { Expected penalty rate (commodity taxes) }=0.07 \text {, Expected penalty rate (income taxes) }=0.2\end{array}$} \\
\hline & \multicolumn{2}{|c|}{ POOR Household } & \multicolumn{2}{|c|}{ RICH Household } \\
\hline & $\begin{array}{l}\text { Magnitude } \\
(\%)\end{array}$ & $\begin{array}{l}\text { Percent Change } \\
(\%)\end{array}$ & $\begin{array}{l}\text { Magnitude } \\
(\%)\end{array}$ & $\begin{array}{l}\text { Percent Change } \\
(\%)\end{array}$ \\
\hline Initial Post-Evasion Welfare & 3.01 & \multirow[b]{2}{*}{-22.9} & -0.58 & \multirow[b]{2}{*}{101.7} \\
\hline Final Post-Evasion Welfare & 2.32 & & 0.01 & \\
\hline Initial Price of Good X & 4.10 & \multirow[b]{2}{*}{-8.5} & 4.10 & \multirow[b]{2}{*}{-8.5} \\
\hline Final Price of Good X & 3.75 & & 3.75 & \\
\hline Initial Price of Good Y & -6.89 & \multirow[b]{2}{*}{10.3} & -6.89 & \multirow[b]{2}{*}{10.3} \\
\hline Final Price of Good Y & -6.18 & & -6.18 & \\
\hline Initial Post-Evasion Rental Rate & -0.82 & \multirow[b]{2}{*}{412.1} & -0.82 & \multirow[b]{2}{*}{412.1} \\
\hline Final Post-Evasion Rental Rate & 2.56 & & 2.56 & \\
\hline Initial Post-Evasion Net Wage & -3.89 & \multirow[b]{2}{*}{-15.1} & -0.54 & \multirow[b]{2}{*}{-112.9} \\
\hline Final Post-Evasion Net Wage & -4.48 & & -1.15 & \\
\hline Initial Post-Evasion Labor Supply & 7.27 & \multirow[b]{2}{*}{61.8} & -2.13 & \multirow[b]{2}{*}{159.6} \\
\hline Final Post-Evasion Labor Supply & 11.77 & & 1.27 & \\
\hline \multicolumn{5}{|c|}{$\begin{array}{l}\text { Statutory ad valorem commodity tax }=0.1 \text {, Statutory proportional income tax rate }=0.25 \\
\text { Expected penalty rate (commodity taxes) }=0.095 \text {, Expected penalty rate (income taxes) }=0.225\end{array}$} \\
\hline Initial Post-Evasion Welfare & 1.31 & \multirow[b]{2}{*}{-24.4} & -0.23 & \multirow[b]{2}{*}{121.7} \\
\hline Final Post-Evasion Welfare & 0.99 & & 0.05 & \\
\hline Initial Price of Good X & 1.75 & \multirow[b]{2}{*}{-9.1} & 1.75 & \multirow[b]{2}{*}{-9.1} \\
\hline Final Price of Good X & 1.59 & & 1.59 & \\
\hline Initial Price of Good Y & -3.05 & \multirow[b]{2}{*}{-11.2} & -3.05 & \multirow[b]{2}{*}{-11.2} \\
\hline Final Price of Good Y & -2.71 & & -2.71 & \\
\hline Initial Post-Evasion Rental Rate & -0.33 & \multirow[b]{2}{*}{466.7} & -0.33 & \multirow[b]{2}{*}{466.7} \\
\hline Final Post-Evasion Rental Rate & 1.21 & & 1.21 & \\
\hline Initial Post-Evasion Net Wage & -0.94 & \multirow[b]{2}{*}{-27.6} & -0.17 & \multirow[b]{2}{*}{-182.3} \\
\hline Final Post-Evasion Net Wage & -1.20 & & -0.48 & \\
\hline Initial Post-Evasion Labor Supply & 3.14 & \multirow[b]{2}{*}{61.7} & -0.91 & \multirow{2}{*}{170.3} \\
\hline Final Post-Evasion Labor Supply & 5.08 & & 0.64 & \\
\hline
\end{tabular}

Note. "Initial" refers to the outcome with limited competition and/or entry in the informal sector. "Final" refers to the outcome with increased competition and/or entry in the informal sector. "Magnitude" is the percentage difference between the post-evasion and post-tax outcome if both POOR and RICH households complied with taxes. "Percent change" refers to the percentage change between the magnitude for the "initial" and "final" outcome. 


\section{Table 8}

Summary of General Equilibrium Effects: RICH Household Allocates Some Labor to Informal Sector and POOR Household Endowment Is 25 Percent of RICH Household

Endowment

\begin{tabular}{|c|c|c|c|c|}
\hline \multicolumn{5}{|c|}{$\begin{array}{l}\text { Statutory ad valorem commodity tax }=0.1 \text {, Statutory proportional income tax rate }=0.25 \\
\text { Expected penalty rate (commodity taxes) }=0.07 \text {, Expected penalty rate (income taxes) }=0.2\end{array}$} \\
\hline & \multicolumn{2}{|c|}{ POOR Household } & \multicolumn{2}{|c|}{ RICH Household } \\
\hline & $\begin{array}{l}\text { Magnitude } \\
(\%)\end{array}$ & $\begin{array}{l}\text { Percent Change } \\
(\%)\end{array}$ & $\begin{array}{l}\text { Magnitude } \\
(\%)\end{array}$ & $\begin{array}{l}\text { Percent Change } \\
(\%)\end{array}$ \\
\hline Initial Post-Evasion Welfare & 3.40 & \multirow[b]{2}{*}{-24.7} & -0.69 & \multirow[b]{2}{*}{87.5} \\
\hline Final Post-Evasion Welfare & 2.56 & & 0.15 & \\
\hline Initial Price of Good X & 4.19 & \multirow[b]{2}{*}{-3.8} & 4.19 & \multirow[b]{2}{*}{-3.8} \\
\hline Final Price of Good X & 4.03 & & 4.03 & \\
\hline Initial Price of Good Y & -7.23 & \multirow[b]{2}{*}{6.5} & -7.23 & \multirow[b]{2}{*}{6.5} \\
\hline Final Price of Good Y & -6.76 & & -6.76 & \\
\hline Initial Post-Evasion Rental Rate & -1.91 & \multirow[b]{2}{*}{221.4} & -1.91 & \multirow[b]{2}{*}{221.4} \\
\hline Final Post-Evasion Rental Rate & 2.32 & & 2.32 & \\
\hline Initial Post-Evasion Net Wage & -3.03 & \multirow[b]{2}{*}{-30.3} & -0.31 & \multirow[b]{2}{*}{-75.2} \\
\hline Final Post-Evasion Net Wage & -3.95 & & -1.25 & \\
\hline Initial Post-Evasion Labor Supply & 6.84 & \multirow[b]{2}{*}{88.4} & -1.44 & \multirow[b]{2}{*}{363.1} \\
\hline Final Post-Evasion Labor Supply & 12.89 & & 3.79 & \\
\hline \multicolumn{5}{|c|}{$\begin{array}{l}\text { Statutory ad valorem commodity tax }=0.1 \text {, Statutory proportional income tax rate }=0.25 \\
\text { Expected penalty rate (commodity taxes) }=0.095 \text {, Expected penalty rate (income taxes) }=0.225\end{array}$} \\
\hline Initial Post-Evasion Welfare & 1.46 & \multirow[b]{2}{*}{-26.7} & -0.26 & \multirow[b]{2}{*}{142.3} \\
\hline Final Post-Evasion Welfare & 1.07 & & 0.11 & \\
\hline Initial Price of Good X & 1.77 & \multirow[b]{2}{*}{-3.9} & 1.77 & \multirow[b]{2}{*}{-3.9} \\
\hline Final Price of Good X & 1.70 & & 1.70 & \\
\hline Initial Price of Good Y & -3.18 & \multirow[b]{2}{*}{7.5} & -3.18 & \multirow[b]{2}{*}{7.5} \\
\hline Final Price of Good Y & -2.94 & & -2.94 & \\
\hline Initial Post-Evasion Rental Rate & -0.77 & \multirow[b]{2}{*}{246.7} & -0.77 & \multirow[b]{2}{*}{246.7} \\
\hline Final Post-Evasion Rental Rate & 1.13 & & 1.13 & \\
\hline Initial Post-Evasion Net Wage & -0.55 & \multirow[b]{2}{*}{-42.7} & -0.19 & \multirow[b]{2}{*}{-168.4} \\
\hline Final Post-Evasion Net Wage & -0.96 & & -0.51 & \\
\hline Initial Post-Evasion Labor Supply & 2.94 & \multirow[b]{2}{*}{87.4} & -0.61 & \multirow[b]{2}{*}{383.6} \\
\hline Final Post-Evasion Labor Supply & 5.51 & & 1.73 & \\
\hline
\end{tabular}

Note. "Initial" refers to the outcome with limited competition and/or entry in the informal sector. "Final" refers to the outcome with increased competition and/or entry in the informal sector. "Magnitude" is the percentage difference between the post-evasion and post-tax outcome if both POOR and RICH households complied with taxes. "Percent change" refers to the percentage change between the magnitude for the "initial" and "final" outcome. 